\title{
GRANULAR ACTIVATED CARBON AS NUCLEUS FOR FORMATION OF ANAMMOX GRANULES IN AN EXPANDED GRANULAR-SLUDGE-BED REACTOR
}

\author{
WENJIE Z. ${ }^{1, *}$ \\ HUAQIN W. ${ }^{1}$ \\ JOSEPH D.R. ${ }^{2}$ \\ YUE J. ${ }^{3}$
}

${ }^{1}$ Guangxi Scientific Experiment Center of Mining, Metallurgy and Environment
Guilin University of Technology, 12, Jiangan Road, Guilin, 541004, P.R. China
${ }^{2}$ Water and Environmental Research Institute of the Western Pacific
University of Guam, UOG Station, Mangilao, 96923, Guam, USA
${ }^{3}$ College of Civil Engineering and Architecture, Guilin University of Technology
12 , Jiangan Road, Guilin, 541004, P.R. China

Received: 02/06/2014

Accepted: 03/06/2015

Available online: 24/06/2015 *to whom all correspondence should be addressed: e-mail: zhangwj_zhangwj@hotmail.com

\section{ABSTRACT}

Granular activated carbon (GAC) was used in an Anammox process treating synthetic wastewater with the aim of evaluating its use as a growth nucleus to enhance granule formation. In an expanded granularsludge-bed reactor, granules were formed demonstrating excellent retention characteristics with an average settling velocity of $200 \mathrm{~m} \mathrm{~h}^{-1}\left(5 \mathrm{~cm} \mathrm{~s}^{-1}\right)$ over a startup period of only 38 days. The time required for formation of Anammox granules under the experimental conditions in this study, was thus demonstrated to be much shorter than that of others. A genetic analysis of the organisms in the granular bed revealed an abundance of Paenisporosarcina uncultured bacterium similar to other known Anammox bacteria.

Keywords: Anaerobic ammonium oxidation (Anammox); GAC; Granulation;

\section{Introduction}

Since the original report of anaerobic ammonium oxidation (Anammox) in 1995 (Mulder et al., 1995), this innovative technology has undergone rapid development for use in wastewater treatment (Kuenen, 2008; Susanne, 2014). Anammox biomass granules were first observed in a full-scale rector (van der Star et al., 2007) around six years ago; subsequently, very high nitrogen loading rates (NLRs) up to $27 \mathrm{~g} \mathrm{l}^{-1} \mathrm{~d}^{-1}$ have been successfully treated by an expanded granular-sludge-bed (EGSB) reactor using Anammox granules (Chen et al., 2014). Those results are some 50 times higher than that of conventional denitrification processes, which are typically below $0.5 \mathrm{~g} \mathrm{l}^{-1} \mathrm{~d}^{-1}$. Though the use of Anammox granules for wastewater treatment has been well documented (Alvarino et al., 2015), the initial formation of Anammox granules, which can take several months to years, is a subject that is often overlooked. In addition, even apart from the granulation question, Anammox bacteria have a doubling time of approximately 11 days (Kuenen, 2008), which is even longer than that of methane producing bacteria (MPB). From an engineering standpoint, enhancing Anammox granule formation is one of the most important and challenging factors in this field.

The granulation process can be divided into two steps, aggregation of inert particles and biofilm formation on the inert aggregates. To accelerate the granulation process, the addition of inert particles has been considered for the formation of methane-producing granules. Synthetic and natural polymers such as synthetic Percol 763, chitosan, and a cationic polymer have been reported to enhance granulation (Tiwari 
et al., 2005; Ni et al., 2015), but the results have not been consistent and the granules were smaller than those of a typical granular sludge (Xing et al., 2015). Thus, an appropriate material to use as an inert seed for granulation of Anammox biomass is urgently needed. The preferred characteristics of such a material would include having a high specific surface area, relatively high specific gravity, near spherical shape and low production cost.

In this study, granular activated carbon (GAC) was used for evaluation of its effectiveness as a seed for granule formation. GAC has a porous microstructure suitable for retention of bacteria and a specific gravity slightly heavier than that of water, and was thus thought to be a suitable candidate for use in an Anammox reactor treating high-strength wastewater. Genetic analysis using the 16S rRNA gene was employed to characterize the microbial population of the GAC-based Anammox granules.

\section{Materials and methods}

\subsection{Anammox reactor}

The reactor had an inner diameter of $14 \mathrm{~cm}$ with a total liquid volume of $10 \mathrm{I}$ including a reaction zone of $8 \mathrm{~L}$ and a settling zone of $2 \mathrm{I}$ (Fig. 1). The reactor was made of acrylic resin and had a water jacket for temperature control. Sampling ports were located at heights of 3, 17, 20 and $25 \mathrm{~cm}$ above the reactor bottom. Part of the effluent was collected in a 5-L container (with mixer and heater) for use as recycle. The $\mathrm{pH}$ was adjusted by an online $\mathrm{pH}$ controller (TPH/T-10, Tengine, China) using $0.5 \mathrm{~mol} \mathrm{I}^{-1} \mathrm{H}_{2} \mathrm{SO}_{4}$. The reactor was enclosed in a black-vinyl sheet to inhibit growth of photosynthetic bacteria and algae.

The reactor was operated in up-flow mode, with influent introduced at the bottom using a peristaltic pump (BT100-2J, LongerPump, China). A recirculation pump (BT600-2J, LongerPump, China) was used to dilute the influent with the treated wastewater in the 5 -I recycle container.

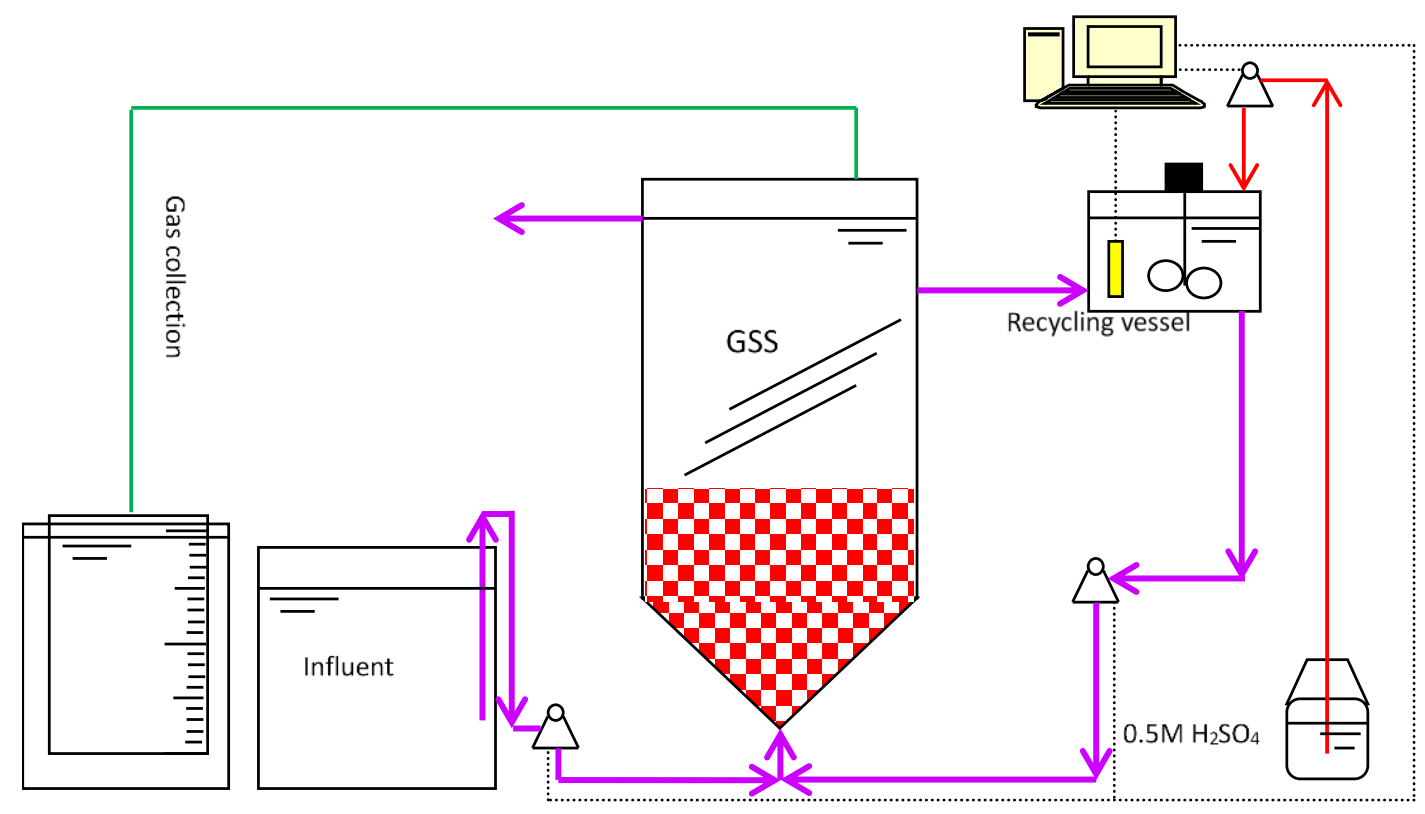

Figure 1. Schematic view of the Anammox reactor system

Symbols: GSS, Gas Solid Separator.

\subsection{Seed sludge}

The Anammox seed sludge used in the reactor was generously provided by Kumamoto University (Zhang et al., 2014). The initial seeding concentration (mass of mixed liquor suspended solids (MLSS) per liter) was set at $2 \mathrm{~g} \mathrm{MLSS}^{-1}$. 


\section{3. $G A C$}

The original GAC (Ruicheng, China) had an average diameter of 2-3 mm, apparent specific gravity of 0.45 , and a porous microstructure suitable for retention of bacteria. The GAC bed was easily expanded, being only slightly heavier than water. Prior to use, the GAC was black in color and had an average settling velocity of $150 \mathrm{~m} \mathrm{~h}^{-1}$. In total, $2 \mathrm{~L}$ of GAC were added to the reactor in this study.

\subsection{Feed media}

The reactor was fed with synthetic wastewater with a nitrite to ammonium molar ratio of 1.0-1.2. Anammox nutrient medium consisted of 200-1000 mg- $\mathrm{Nl}^{-1}\left(\mathrm{NH}_{4}\right) 2 \mathrm{SO}_{4}, 200-1000 \mathrm{mg}-\mathrm{N} \mathrm{I}^{-1} \mathrm{NaNO}_{2}, 1500 \mathrm{mg}$ $\mathrm{I}^{-1} \mathrm{KHCO}^{3}, 50 \mathrm{mg} \mathrm{l}^{-1} \mathrm{KH}_{2} \mathrm{PO}_{4}, 200 \mathrm{mg} \mathrm{l}^{-1} \mathrm{MgSO}_{4} \cdot 2 \mathrm{H}_{2} \mathrm{O}, 226 \mathrm{mg} \mathrm{l}^{-1} \mathrm{CaCl}_{2} \cdot 2 \mathrm{H}_{2} \mathrm{O}$, and $1 \mathrm{ml}$ of trace element solution I and II (Zhang et al., 2014). The influent storage tank was flushed with nitrogen gas to maintain DO under $0.5 \mathrm{mg} \mathrm{l}^{-1}$, and $\mathrm{Na}_{2} \mathrm{SO}_{3}$ was added to a concentration of $40 \mathrm{mg} \mathrm{l}^{-1}$ (shown to be harmless to Anammox bacteria, data not shown) to keep the DO level close to zero.

\subsection{Analytical method}

$\mathrm{NO}_{2}-\mathrm{N}$ was measured by the colorimetric method according to Standard Methods (4500- $\mathrm{NO}_{2^{-}}, \mathrm{B} ; \mathrm{APHA}$, 1995). $\mathrm{NH}_{4}-\mathrm{N}$ was measured by the phenate method according to Kanda (1995). Total nitrogen (TN) was determined by the persulfate method (4500-N, C; APHA, 1995) using the UV spectrophotometric screening method (4500- $\left.\mathrm{NO}_{3}-, \mathrm{B} ; \mathrm{APHA}, 1995\right)$ for quantification of $\mathrm{TN}$ as $\mathrm{NO}_{3}-\mathrm{N}$ (the oxidization product of the persulfate digestion). $\mathrm{NO}_{3}-\mathrm{N}$ (of the original sample) was determined by calculation of the difference of TN and the sum of $\mathrm{NO}_{2}-\mathrm{N}$ and $\mathrm{NH}_{4}-\mathrm{N}$. The $\mathrm{pH}$ was measured by using a pH meter (9010, Jenco, USA), and dissolved oxygen (DO) was measured by using a DO meter (6010, Jenco, USA).

The suspended solids (SS) content was determined according to Standard Methods (2540-Solids, D; APHA, 1995). The total sludge content was estimated as mixed-liquor suspended solids (MLSS). For determination of MLSS, a sludge sample of known volume was washed twice by centrifuging at $1000 \mathrm{Xg}$ for 15 min with decanting and re-suspending in deionized water and then dried to a constant weight at $105^{\circ} \mathrm{C}$, with cooling to room temperature under desiccation prior to weighing.

\subsection{Scanning electron microscopy (SEM)}

Samples were first washed in a $0.1 \mathrm{M}$ phosphate buffer solution $(\mathrm{pH} 7.4)$ for $5 \mathrm{~min}$. Then samples were hardened for $90 \mathrm{~min}$ in a $2.5 \%$ glutaraldehyde solution prepared with the buffer solution. Next, samples were washed in the buffer solution three times for $10 \mathrm{~min}$ each and then fixed for $90 \mathrm{~min}$ in a $1.0 \% \mathrm{OsO}_{4}$ solution prepared with the buffer solution. After washing samples three times for $10 \mathrm{~min}$ each in the buffer solution, they were dewatered for $10 \mathrm{~min}$ each in serially graded solutions of ethanol at concentrations of $10 \%, 30 \%, 50 \%, 70 \%, 90 \%$, and $95 \%$. SEM observations were conducted by using a scanning electron microscope (JSM-6380LV, JEOL, Tokyo).

\subsection{DNA extraction and high-throughput 16s rRNA gene pyrosequencing}

After 139 days of operation, the particle based granules were taken out from the Anammox reactor. A granular sludge sample was first ground with a pestle under liquid nitrogen. Meta-genomic DNA was extracted using the E.Z.N.A. Soil DNA Kit (OMEGA Biotec. D5625-01, USA) according to the manufacturer's instructions. Amplification of the 16S rRNA gene was performed using primers 27F (forward primer: 5'AGAGTTTGATCCTGGCTCAG-3') and 533R (reverse primer: 5'-TTACCGCGGCTGCTGGCAC-3'). PCR was carried out according to the following thermocycling parameters: $120 \mathrm{~s}$ initial denaturation at $95^{\circ} \mathrm{C}, 25$ cycles of $30 \mathrm{~s}$ at $95^{\circ} \mathrm{C}, 30 \mathrm{~s}$ at $55^{\circ} \mathrm{C}, 30 \mathrm{~s}$ at $72^{\circ} \mathrm{C}, 5 \mathrm{~min}$ final elongation at $72^{\circ} \mathrm{C}$, then held at $10^{\circ} \mathrm{C}$ until halted by user. Duplicate PCR products were pooled and purified using the AXYGEN gel extraction kit (Axygen, USA) (Isanta et al., 2015).

Pyrosequencing was carried out by a 454 Life Sciences Genome Sequencer FLX Titanium instrument (Roche). Sequences were clustered into operational taxonomic units (OTUs) by setting a 0.03 distance limit (equivalent to $97 \%$ similarity) using the MOTHUR program. 


\section{Results}

\subsection{Reactor performance}

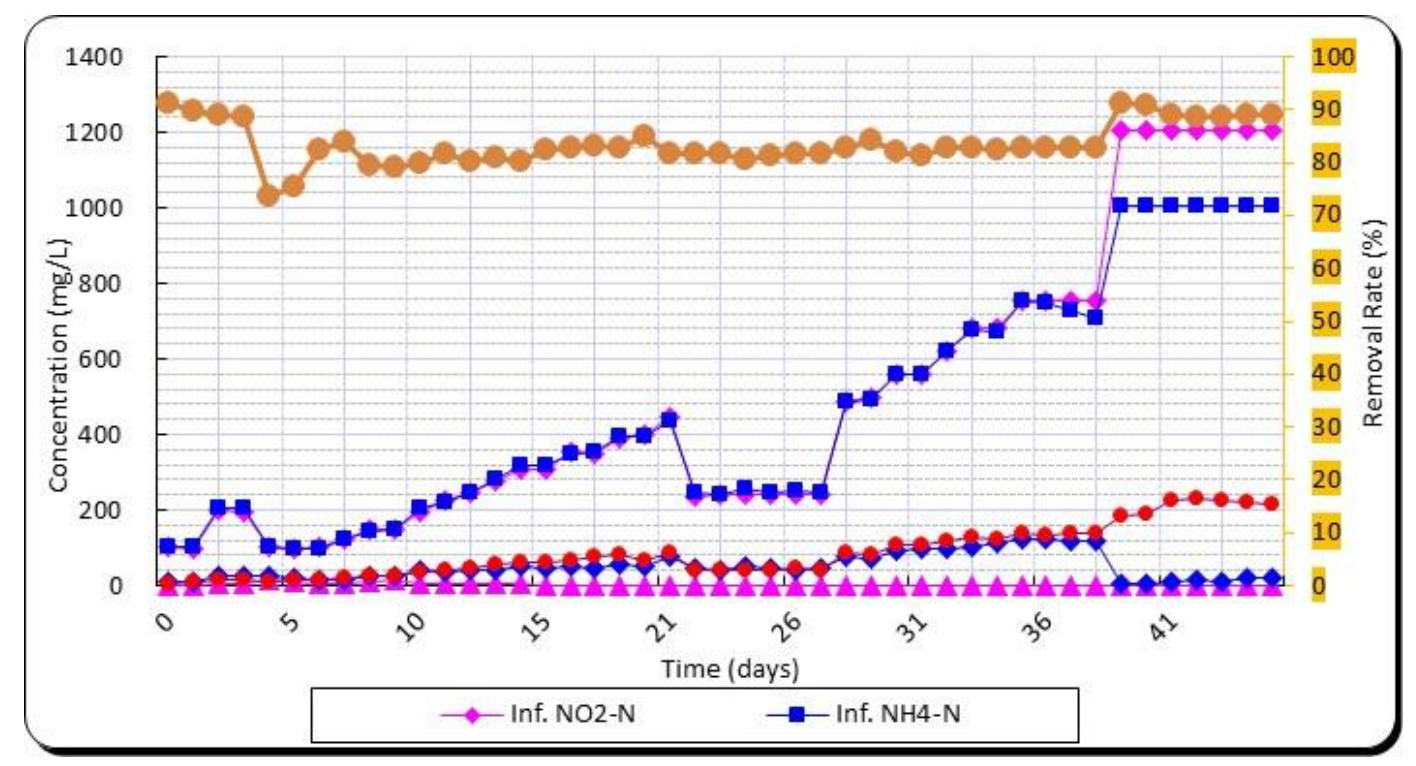

(a)

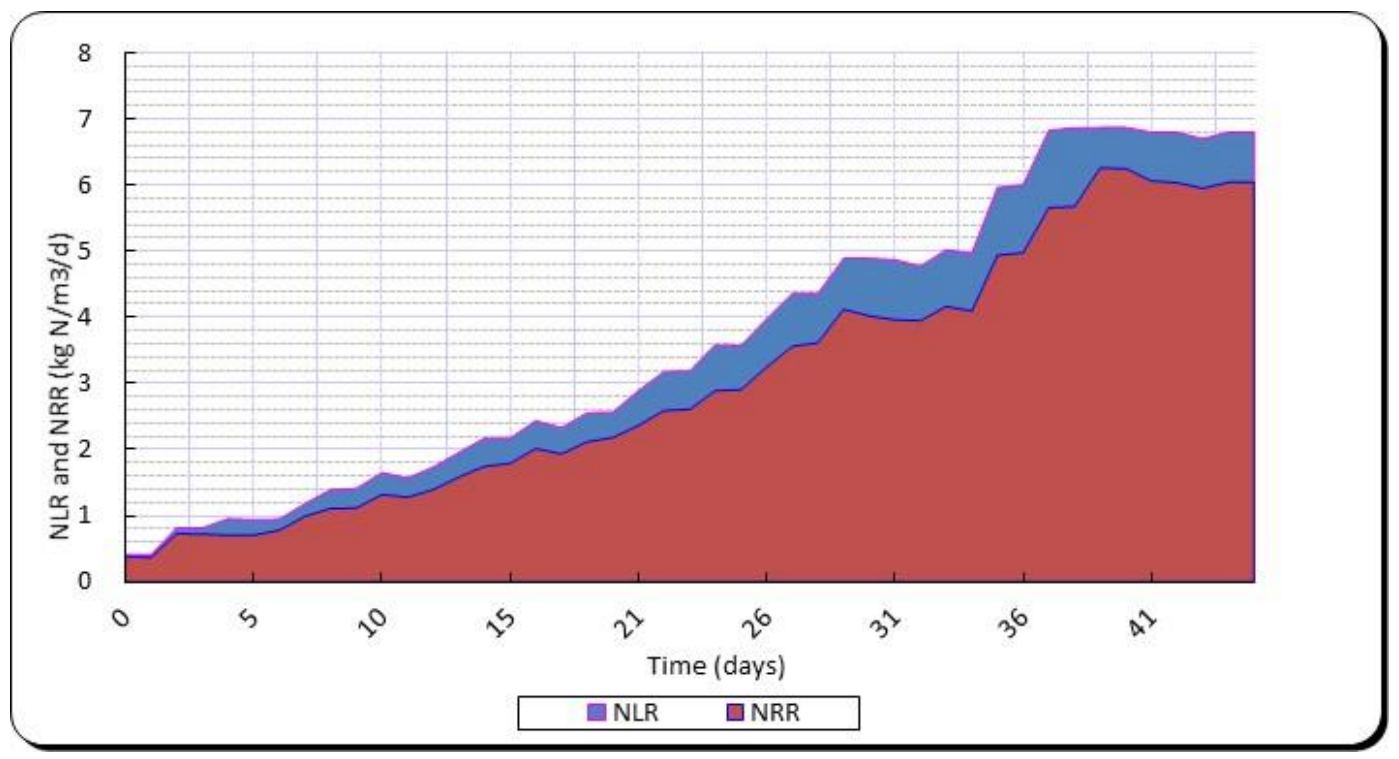

(b)

Figure 2. Reactor performance during the study

The start-up period for the Anammox reactor was considered to be from day 0 to day 35 (Fig. 2), during which time the NLR was increased from 0.5 to $6 \mathrm{~kg}-\mathrm{N} / \mathrm{m}^{3} /$ day by shortening the HRT from 12 to $1.6 \mathrm{~h}$ and increasing the influent TN from 174 to $490 \mathrm{mg} \mathrm{l}^{-1}$. The corresponding NRR achieved on day 35 was $4.8 \mathrm{~kg}$ 
$\mathrm{N} / \mathrm{m}^{3} /$ day corresponding to a TN removal efficiency of $84 \%$, which is corroborative of the stoichiometric expectation for a complete Anammox reaction (Kuenen, 2008).

Subsequently, from day 35 to day 46 (Fig. 2), influent TN concentrations were increased stepwise to 1000 $\mathrm{mg} \mathrm{l}^{-1}, 1500 \mathrm{mg} \mathrm{l}^{-1}$, and $2200 \mathrm{mg} \mathrm{l}^{-1}$ to probe the treatment potential of the EGSB reactor under a constant $\mathrm{NLR}$ of $6 \mathrm{~kg}-\mathrm{N} / \mathrm{m}^{3} /$ day (maintained by decreasing the influent flow rate).

Throughout the study, the temperature in the reactor was maintained at $33 \pm 1^{\circ} \mathrm{C}$, and the DO concentration was held below $0.5 \mathrm{mg} \mathrm{l}^{-1}$. Furthermore, the effluent $\mathrm{pH}$ (7.6-8.2) was notably higher than that in the influent (6.9-7.2), which is due to consumption of acidity in the Anammox reaction (Kuenen, 2008).

\subsection{GAC granules}
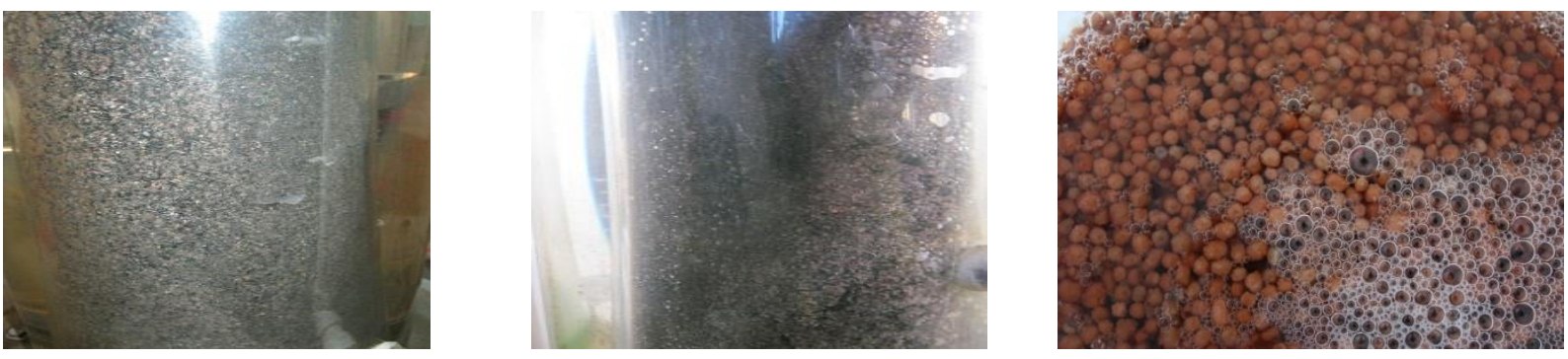

Figure 3. Appearance of GAC on days 1, 15, 35

At first the GAC was black in color and the Anammox sludge was red. The variations in appearance were recorded using a digital camera at 15 to 20 -day intervals throughout the study (Fig. 3). Within one month, the GAC had become red due to the growth of Anammox bacteria in the biofilm attached to the GAC. The matured, red GAC-seeded granules (Fig. 3) had an average settling velocity $200 \mathrm{~m} \mathrm{~h}^{-1}\left(5 \mathrm{~cm} \mathrm{~s}^{-1}\right)$, compared to typical values for biomass granules of 73 to $88 \mathrm{~m} \mathrm{~h}^{-1}$ (Tang et al., 2011). Some fragments from crushed granules washed-out of the reactor, which suggests that the increased density of the mature GAC-based granules is instrumental in enhancing sedimentation and retention of the essential biomass, which could also reduce the occurrence of floating loss due to gas generation activity.

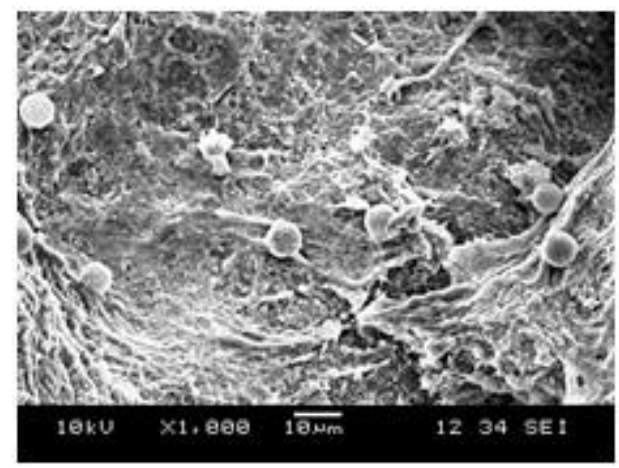

day 1

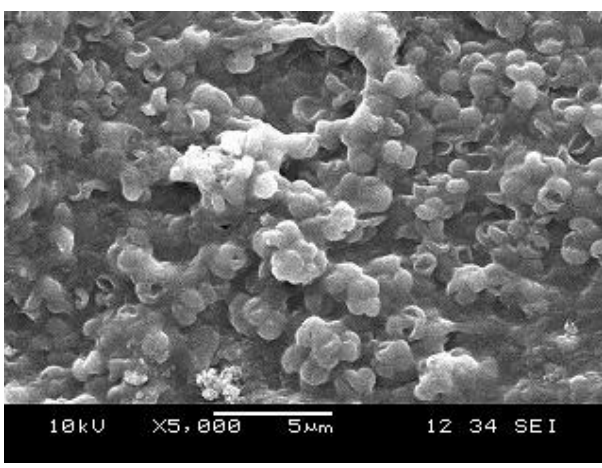

day 38

Figure 4. SEM microphotograph of GAC

The Anammox biomass granules seeded with GAC were similar in appearance to granules reported by others (Abma et al., 2007). SEM micrographs (Fig. 4) indicate that a relative large numbers of bacteria were attached to the GAC nuclei. The spaghetti theory suggests that filamentous microorganisms form a frame or mesh by which other bacteria such as cocci are trapped and retained, which leads to granule growth, as appears to be the case here. 


\section{Discussion}

Seed particles have often been employed to enhance the granulation process in traditional UASB reactors. Imajo et al., (2004) studied the feasibility of granulation in an Anammox process using granules from a UASB reactor as seed material, by which an effective granule bed of the extremely slow-growing Anammox microorganisms was achieved in approximately 25 weeks. Compared to the original full-scale UASB reactor (Abma et al., 2007), the start-up period was greatly reduced, though nonetheless still considered prohibitively long. Comparatively, the formation of an Anammox granular bed in this study using a GAC seed was accomplished within 5 weeks while gradually increasing the NLR to $6 \mathrm{~kg}-\mathrm{N} / \mathrm{m}^{3} / \mathrm{d}$. In addition, the temporary flux of high effluent ammonia concentrations that would be expected due to the degradation of the seed granules from a UASB reactor was avoided during this study due to seeding only with GAC.

Although the functions of co-existing bacteria in Anammox consortia are largely unknown, the Uncultured bacterium clone KIST-JJY024 and Uncultured bacterium cloneFN-11 are considered to be key organisms in the granulation process. In this study, though, the GAC is thought to have provided the necessary environmental characteristics for growth of Anammox bacteria, such as the protective niches with growth-supportive surfaces. Nonetheless, the co-existing organisms soon adapted to the conditions employed here and obtained prevalence in the consortium. Over most of the study, only $25 \%$ of the total clones were identified as Anammox bacteria (maintained until the final period of the study when the influent TN was greater than $2 \mathrm{~g} \mathrm{l}^{-1}$ ). Very high TN removal rates, though, were obtained indicating that the Anammox bacteria in the granular medium were uninhibited and highly active, obtaining a specific removal rate of $1.44 \mathrm{~g} \mathrm{TN} / \mathrm{L} \mathrm{GAC/day}$.

As shown in Fig. 3(b), the influent TN concentration was increased to $2200 \mathrm{mg} \mathrm{l}^{-1}$ with the nitrogen removal efficiency above $89 \%$ and the NRR at $6 \mathrm{~kg} \mathrm{~N} / \mathrm{m} 3 / \mathrm{d}$ (process hydraulic retention time of $8.8 \mathrm{~h}$ ) near the end of the study. High NO2-N concentrations are inhibitory to Anammox bacteria (Carvajal-Arroyo et al., 2014); thus, highly concentrated nitrogen wastewater is usually diluted prior to treatment in Anammox reactors (Yamamoto et al., 2011). However, this practice is forbidden by law for wastewater treatment in China. Accordingly, the GAC-seeded Anammox reactor as demonstrated here could have a very effective application for high-strength wastewaters.

The predominant bacteria in this study are Uncultured bacterium clone KIST-JJY024, Uncultured bacterium cloneFN-11, Uncultured bacterium clone KIST-JJY012, and Uncultured bacterium clone: AnSal09, which is a population balance clearly different from others cases, which shows that the GAC seed acts well not only as a biofilm carrier by replacing the structural function of filamentous growth, but also by evidently stimulating the growth of Uncultured bacterium clone KIST-JJYO24 and Uncultured bacterium clone FN-11, which are well known as key components of Anammox granulation and may have been involved in extending the granulation process external to the GAC. Thus, it is considered that the added GAC seed used in this study can function effectively as nucleus particles by which the formation of granules can be readily enhanced.

\section{Conclusions}

Using GAC as seed for granulation of Anammox biomass, startup of an EGSB reactor was achieved in over a five-week period. The red, matured granules demonstrated excellent retention characteristics with an average settling velocity of $200 \mathrm{~m} \mathrm{~h}^{-1}\left(5 \mathrm{~cm} \mathrm{~s}^{-1}\right)$. The potential roll of GAC in providing a medium well suited for growth of co-existing bacteria and thus enhancing granule formation was discussed.

\section{Acknowledgements}

This research was supported by the National Natural Science Foundation of China (No. 51108108), Guangxi Natural Science Foundation (2013GXNSFCA019018; 2014 GXNSFBA118265), Research Projects of the Education Department of Guangxi Government (2013ZD031; 2013ZL076; ZL2014051; KY2015ZL118), The Project of High Level Innovation 
Team and Outstanding Scholar in Guangxi Colleges and Universities, Guangxi Key Laboratory of New Energy and Building Energy Saving (12-J-21-2).

\section{References}

Abma W.R., Schultz C.E., Mulder J.W., Van der Star W.R.L., Strous M., Tokutomi T. and Van Loosdrecht M.C.M. (2007), Full-scale granular sludge Anammox process, Water Sci. Technol., 55, 27-33.

Alvarino T., Suarez S., Katsou E., Vazquez-Padin J., Lema J.M. and Omil F. (2015), Removal of PPCPs from the sludge supernatant in a one stage nitritation/anammox process, Water Res., 68, 701-709.

APHA (1995), Standard method for the examination of water and wastewater, 19th ed. American Public Health Association, Washington, D.C.

Bhunia P. and Ghangrekar M.M. (2007), Required minimum granule size in UASB reactor and characteristics variation with size, Biores. Technol., 98, 994-999.

Carvajal-Arroyo J.M., Puyol D., Li G., Lucero-Acuña A., Sierra-Álvarez R. and Field J.A. (2014), Pre-exposure to nitrite in the absence of ammonium strongly inhibits anammox, Water Res., 48, 52-60.

Chen H., Ma C., Yang G., Wang H., Yu Z. and Jin R. (2014), Floatation of flocculent and granular sludge in a highloaded anammox reactor, Biores. Technol., 169, 409-415.

Imajo U., Tokutomi T. and Furukawa K. (2004), Granulation of Anammox microorganisms in up-flow reactors, Water Sci. Technol., 49, 155-163.

Isanta E., Bezerra T., Fernández I., Suárez-Ojeda M.E., Pérez J. and Carrera J. (2015), Microbial community shifts on an anammox reactor after a temperature shock using 454-pyrosequencing analysis, Biores. Technol., 181, 207-213.

Kanda J. (1995), Determination of ammonium in seawater based on the indophenol reaction with o-Phenylphenol (OPP), Wat. Res., 29, 2746-2750.

Kuenen J.G. (2008), Anammox bacteria: from discovery to application, Nat. Rev. Microbiol., 6, 320-326.

Mulder A., Van de Graaf A.A., Robertson L.A. and Kuenen J.G. (1995), Anaerobic ammonium oxidation discovered in a denitrifying fluidized bed reactor, FEMS Microbiol. Ecology., 16, 177-184.

Ni S., Sun N., Yang H., Zhang J. and Ngo H.H. (2015), Distribution of extracellular polymeric substances in anammox granules and their important roles during anammox granulation, Biochem. Eng. J., 101, 126-133.

Susanne L., Eva M.G., Siegfried E.V., Adriano J., Harald H. and van Loosdrechtd M.C.M. (2014), Full-scale partial nitritation/anammox experiences - An application survey, Water Res., 55, 292-303.

Tang C.J., Zheng P., Wang C., Mahmood Q., Zhang J., Chen X., Zhang L. and Chen J. (2011), Performance of highloaded ANAMMOX UASB reactors containing granular sludge, Water Res., 45, 135-144.

Tiwari M.K., Guhaa S., Harendranath C.S. and Tripathi S. (2005), Enhanced granulation by natural ionic polymer additives in UASB reactor treating low-strength wastewater, Water Res., 39, 3801-3810.

Van der Star W.R., Abma W.R., Blommers D., Mulder J.W., Tokutomi T., Strous M. and Van Loosdrecht M. (2007), Startup of reactors for anoxic ammonium oxidation: experiences from the first full-scale ANAMMOX reactor in Rotterdam, Water Res., 41, 4149-4163.

Xing B., Guo Q., Yang G., Zhang Z., Li P., Guo L. and Jin R. (2015), The properties of anaerobic ammonium oxidation (anammox) granules: Roles of ambient temperature, salinity and calcium concentration, Sep. Purif. Technol., 147, 311-318.

Yamamoto T., Wakamatsu S., Qiao S., Hira D., Fujii T. and Furukawa K. (2011), Partial nitritation and Anammox of a livestock manure digester liquor and analysis of its microbial community, Biores. Technol., 102, 2342-2347.

Zhang W., Zhang Y., Li L., Zhang X. and Jin Y. (2014), Fast start-up of EGSB reactor using stored Anammox sludge, Water Sci. Technol., 69, 1469-1474. 